\title{
The Research of Performance Evaluation Index in The Pension Institutions PPP Projects Based on KPI
}

\author{
LU Qiuhong ${ }^{1,2, a}$, CHU Yang ${ }^{1, b}$ \\ ${ }^{1}$ Xi'an University of Architecture and Technology,Xi'an 710055, China; \\ ${ }^{2}$ NINGBO MCC20 CONSTRUCTION CO.,LTD, Ningbo 315800, China. \\ arongyaoamber@163.com, ${ }^{\text {b } k a r e n c y r @ 163 . c o m ~}$
}

Key Words: KPI,The Pension Institutions,PPP,Performance Evaluation Index.

\begin{abstract}
PPP model has not been widely applied to the pension institution construction in China, and correspondingly it is lack of mature performance evaluation index system in terms of the performance evaluation on the pension institution PPP project. Based on CSF method and KPI, this paper will analyze the performance objectives which are established to achieve the set strategic target of the pension institution PPP project, construct a conceptual model of KPI, further establish the performance evaluation index system, and promote the improvement of the performance level during the implementation of the pension institution PPP project.
\end{abstract}

\section{Introduction}

As China has entered into aging society at the end of 20th century, social pension service has been a major problem the government has to confront with[1]. In recent years, Chinese government has put forward a pension service based on home pension, relied on community pension and supplemented with institution pension, and generally established the framework of pension model in China[2]. Substantially, pension institution falls into the category of public goods which shall be invested, constructed and operated by the public sector. However, with the accelerating trend of population aging, merely depending on public investment and resource allocation can far satisfy this development trend. Therefore, on the premise of public sector occupying a predominant role, it is a practical method to construct and operate pension institutions on Public Private Partnership (PPP) model by absorbing private capital. Based on CSF model and KPI, this paper studies the performance evaluation index on pension institution PPP project, constructs a performance evaluation index system in order to provide public sector with thought for the performance evaluation of pension institution PPP project and assist project stakeholders to achieve a higher satisfaction.

\section{Existing Problems in Performance Evaluation on Pension Institution PPP Project in China}

(1) Lack of performance evaluation training

The performance evaluation on PPP project is a systematical and sustaining process which requires personnel that participates the evaluation to equip with high professional qualities. Hence, great importance shall be attached to performance evaluation training and the improvement of professional qualities of relevant personnel in the routine management of the project so as to ensure the accuracy of the project performance evaluation. However, as a matter of fact, there is a scarcity of professional talent in PPP project performance evaluation and shortage of training related to the project in China.

(2) Improper method selection of performance evaluation

Select the performance evaluation method pointedly in accordance with its own features when conducting performance evaluation on the project for every project is embedded with distinctive features. In fact, a great deal of the project evaluation subjects are likely to merely copy the successful experiences of other similar projects and apply their evaluation methods mechanically, which consequently exerts a huge impact on the accuracy of the project performance evaluation. 
(3) Formalization of the performance evaluation implementation

The evaluation schemes prepared by most subjects of the project performance evaluation are much formalized in the implementation. The evaluation personnel generally only conduct a rough performance evaluation on the project at the end of year and seldom analyze and process the evaluation result. Consequently, such formalized performance evaluation fails to play its role in improving the performance level of the project. The correct performance evaluation shall be dynamic and keep an eye on the whole process.

\section{Study Basis of Performance Evaluation Index on Pension Institutions PPP Project}

\subsection{Theoretical Basis}

\subsubsection{Critical Success Factors (CSF)}

Critical Success Factor method is to determine the system information demand on the basis of CSF in the overall plan of management information system[3,4]. There are many factors influencing the achievement of the overall strategic target and performance objectives of the project in the project performance evaluation, among which some factors are critical and major, i.e. CSF. Figure out the critical information set as required for the achievement of the performance objectives via the identification of CSF, and further determine KPI for performance evaluation.

\subsubsection{Key Performance Indicator (KPI)}

KPI, an important instrument for performance evaluation, keeps objectives in all levels consistent with the overall strategic target by decomposing the target level upon level and achieves a better evaluation on the project performance[5]. As for the performance evaluation on pension institution PPP project, in particular on the perspective of public sector, KPI with a selection of performance objectives closely concerned the project embodies the requirements for maximizing VFM (Value for Money)[6].

\subsection{Subjects of Performance Evaluation on Pension Institution PPP Project}

In performance evaluation on pension institution PPP project, the performance evaluation subjects may be the project stakeholders such as public sector and private sector or a third party independent from the project[7,8]. Different subjects have different performance evaluation perspectives. Hence, on the basis of impartiality and the premise of protection of interest of all parties, this paper will establish a performance evaluation index system on the project from the perspective of public sector.

\section{Establishment of Performance Evaluation Index System on Pension Institution PPP Project}

\subsection{Performance Objectives of Stakeholders of Pension Institution PPP Project}

The pension institution project is constructed and operated by PPP model mainly with three categories of participants which are public sector, private sector and the public. As for public sector, the application of PPP model can alleviate government' s financial pressure and aggrandize service provision to pension institutions. As for private sector, it is a new investment field for private capital and a new breakthrough on development model innovation for private sector to participate in the construction and operation of pension institutions. From where the public stand, the pension institution construction under PPP model will alleviate social pension pressure and promote satisfaction of social pension demand. In conclusion, the overall strategic target of pension institution PPP project are to achieve a VFM maximization for public sector, profit maximization for private sector and satisfaction maximization on service for the Public[9,10]. On such basis, 14 performance objectives are obtained by refining the overall strategic target and see table 1 for the details. 
Table1 Performance Objectives for the Three Stakeholders in Pension Institution PPP Project

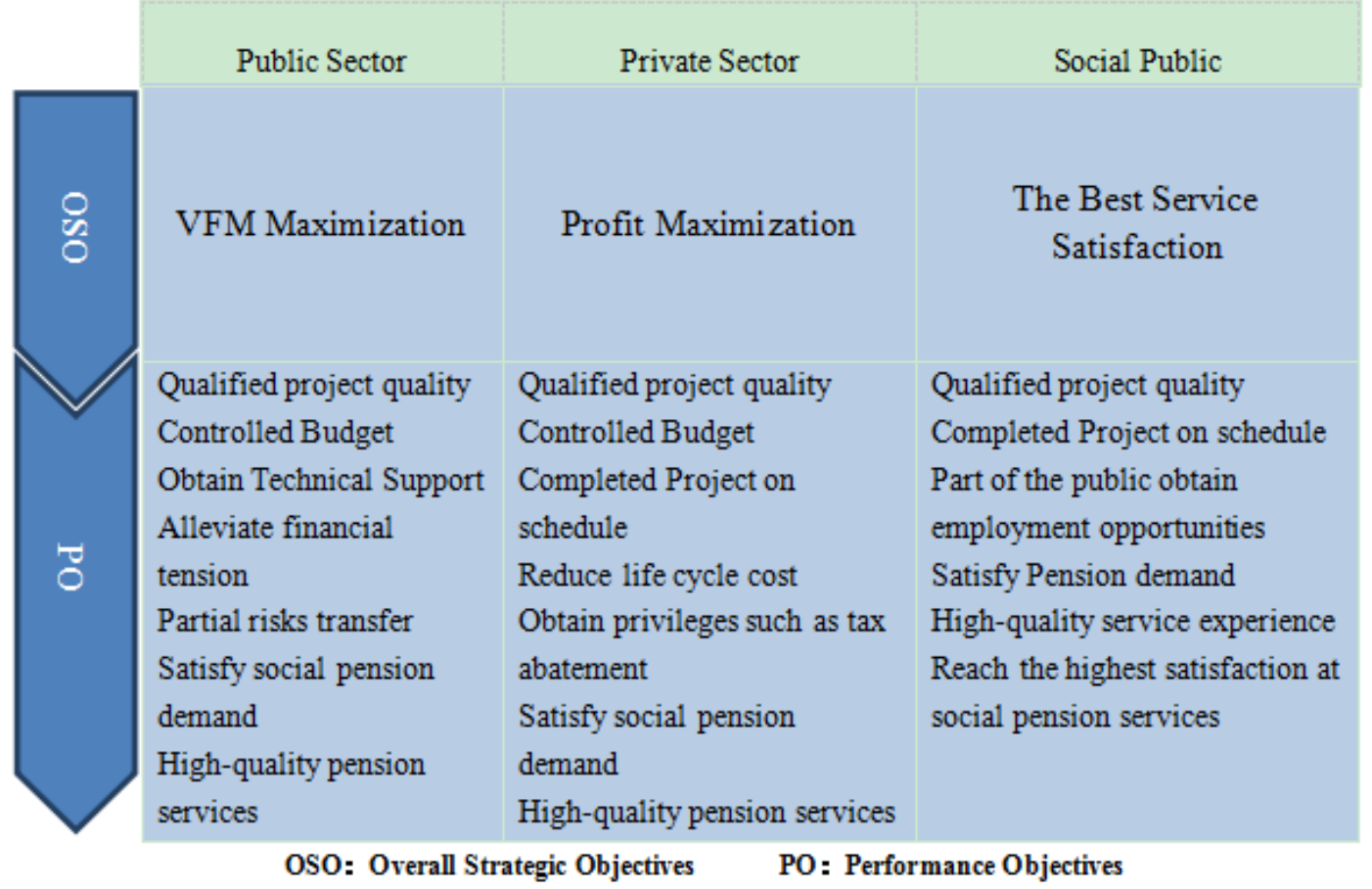

\subsection{Design of Performance Evaluation Index System on Pension Institution PPP Project}

\subsubsection{Identification of CSF in Pension Institution PPP Project}

CSF in pension institution PPP project refers to critical factor which affects the success of performance objectives of stakeholders. From the perspective of public sector, determine CSFs of the project which mainly are social performance, economic performance, stakeholders' satisfaction and sustainable development performance,as shown in Fig.1.

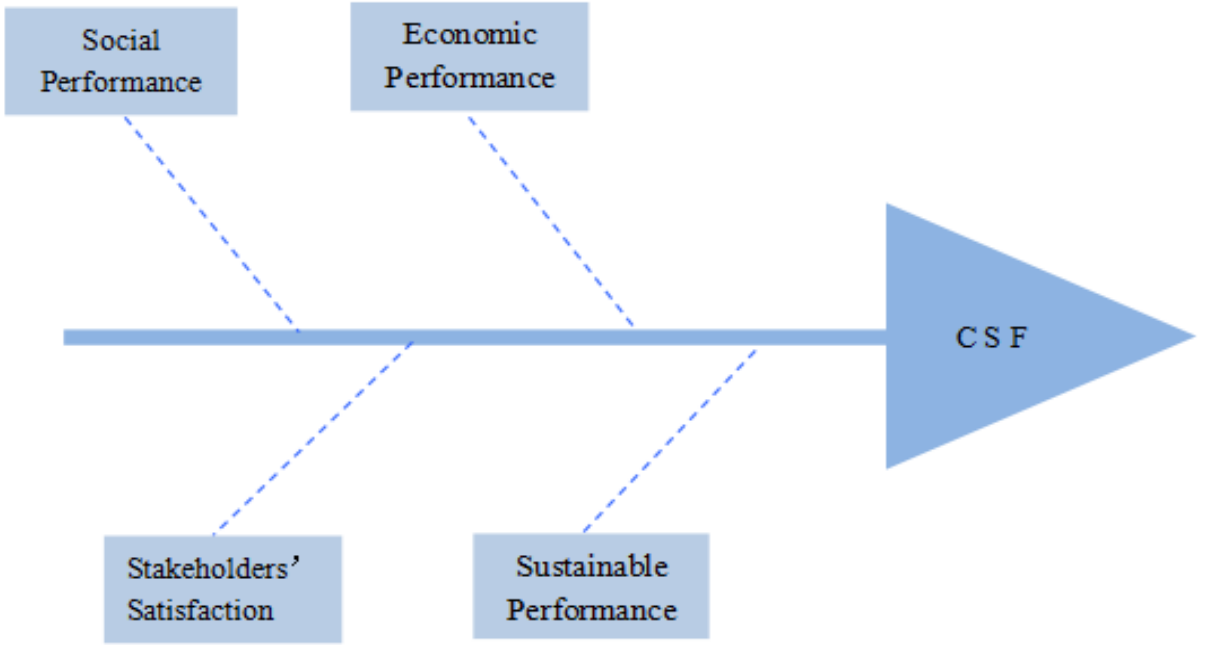

\subsubsection{Construction of KPI Conceptual Model}

Fig.1 CSF in Pension Institution PPP Project

The aforesaid analyses on the performance objectives of the three stakeholders concerned the pension institution PPP project and on the CSF have on set a solid foundation for the following identification of the KPI. In order to better satisfy the demand of each stakeholder, identify the KPI and establish the index system, a conceptual model of KPI shall be constructed in advance which will provide public sector with some ideas on the selection of performance evaluation index for the pension institution PPP project, and see Fig.2 for details. 


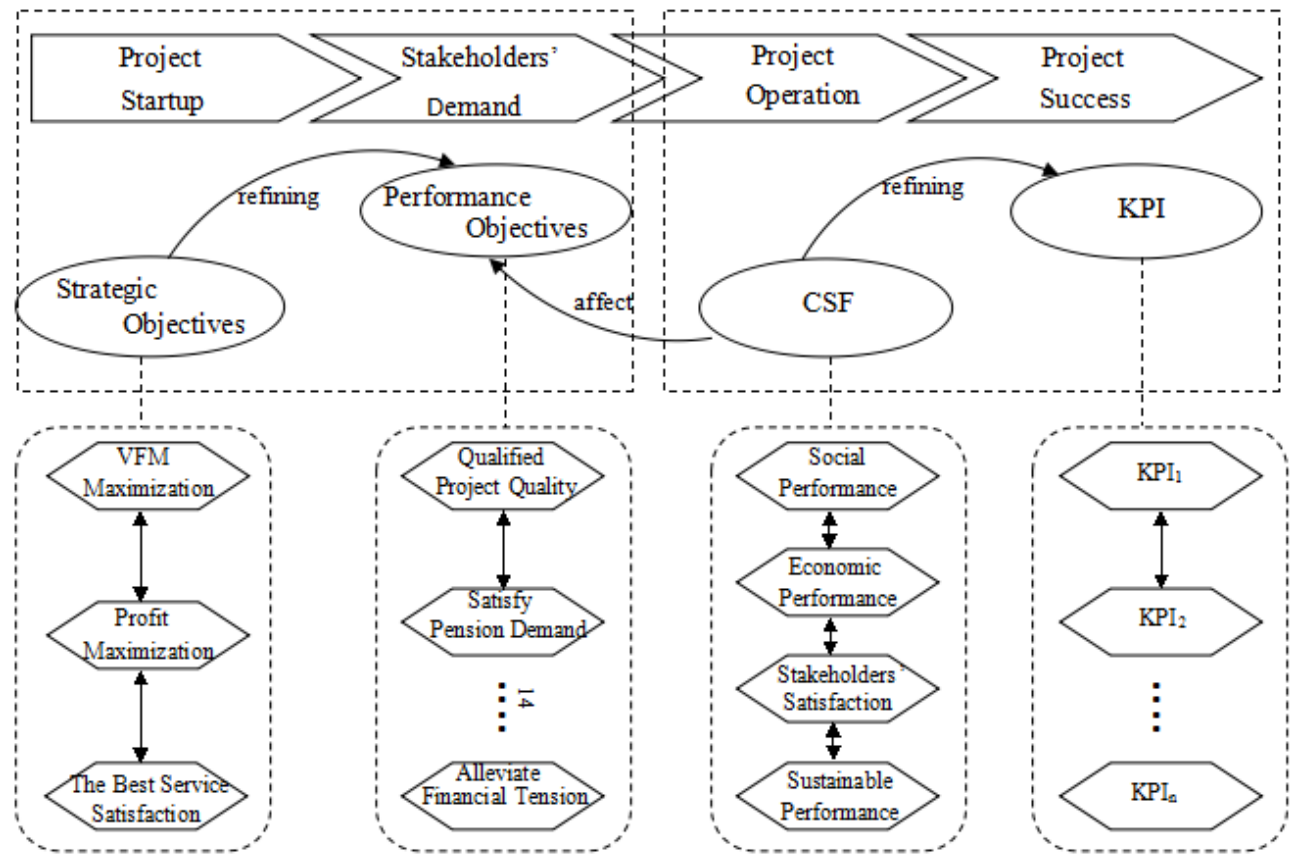

Fig.2 KPI Conceptual Model in Pension Institution PPP Project 4.2.3 Establishment of Performance Evaluation Index System on Pension Institution PPP Project

The core of establishment of performance evaluation index system on pension institution PPP project is to determine KPI. Divide the identified 4 CSF into 11 performance index categories, which are further refined into 29 measurable KPI, and finally establish performance evaluation index system on pension institution PPP project, as shown in table 2.

Table 2 Performance Evaluation Index System on Pension Institution PPP Project

\begin{tabular}{|c|c|c|c|}
\hline $\begin{array}{l}\text { Target } \\
\text { layer }\end{array}$ & $\begin{array}{l}\text { Criterion } \\
\text { layer (CSF) }\end{array}$ & index layer & Sub-index layer (KPI) \\
\hline \multirow{12}{*}{ pension } & \multirow{6}{*}{$\begin{array}{c}\text { Social } \\
\text { performance } \\
\qquad\left(B_{1}\right)\end{array}$} & \multirow{2}{*}{$\begin{array}{l}\text { Society political performance } \\
\left(\mathrm{C}_{1}\right)\end{array}$} & Work efficiency of public sector $\left(\mathrm{D}_{1}\right)$ \\
\hline & & & Decision Ability of public sector $\left(\mathrm{D}_{2}\right)$ \\
\hline & & \multirow{2}{*}{$\begin{array}{l}\text { Society economic performance } \\
\left(\mathrm{C}_{2}\right)\end{array}$} & $\begin{array}{l}\text { Contribution to social personnel employment } \\
\left(\mathrm{D}_{3}\right)\end{array}$ \\
\hline & & & $\begin{array}{l}\text { Contribution to the improvement of social } \\
\text { labor productivity }\left(\mathrm{D}_{4}\right)\end{array}$ \\
\hline & & \multirow{2}{*}{$\begin{array}{l}\text { Society environmental } \\
\text { performance }\left(\mathrm{C}_{3}\right)\end{array}$} & Support and cooperation of the public $\left(\mathrm{D}_{5}\right)$ \\
\hline & & & Contribution to the target population $\left(\mathrm{D}_{6}\right)$ \\
\hline & \multirow{6}{*}{$\begin{array}{l}\text { Economic } \\
\text { performance } \\
\qquad\left(\mathrm{B}_{2}\right)\end{array}$} & \multirow{3}{*}{$\begin{array}{l}\text { Public sector economic } \\
\text { performance }\left(\mathrm{C}_{4}\right)\end{array}$} & VFM value $\left(D_{7}\right)$ \\
\hline & & & Supervision and management expense $\left(D_{8}\right)$ \\
\hline & & & Investment efficiency of public sector $\left(\mathrm{D}_{9}\right)$ \\
\hline & & \multirow{3}{*}{$\begin{array}{l}\text { Private sector economic } \\
\text { performance }\left(\mathrm{C}_{5}\right)\end{array}$} & Investment efficiency of private sector $\left(D_{10}\right)$ \\
\hline & & & Prediction and control of cost $\left(\mathrm{D}_{11}\right)$ \\
\hline & & & Lower financing and financial expense $\left(D_{12}\right)$ \\
\hline
\end{tabular}




\begin{tabular}{|c|c|c|}
\hline \multirow{12}{*}{$\begin{array}{c}\text { Stakeholders' } \\
\text { satisfaction } \\
\left(\mathrm{B}_{3}\right)\end{array}$} & \multirow{5}{*}{ Public sector satisfaction $\left(\mathrm{C}_{6}\right)$} & $\begin{array}{l}\text { Government's satisfaction on the social and } \\
\text { environmental benefit of the project }\left(D_{13}\right)\end{array}$ \\
\hline & & $\begin{array}{l}\text { Government's satisfaction on risk allocation } \\
\left(\mathrm{D}_{14}\right)\end{array}$ \\
\hline & & $\begin{array}{l}\text { Government's satisfaction on project } \\
\text { practicality }\left(\mathrm{D}_{15}\right)\end{array}$ \\
\hline & & $\begin{array}{l}\text { Government's satisfaction on project quality } \\
\left(\mathrm{D}_{16}\right)\end{array}$ \\
\hline & & $\begin{array}{l}\text { Government's satisfaction on public private } \\
\text { partnership }\left(\mathrm{D}_{17}\right)\end{array}$ \\
\hline & \multirow{4}{*}{ Private sector satisfaction $\left(\mathrm{C}_{7}\right)$} & $\begin{array}{l}\text { Private sector satisfaction on economic benefit } \\
\text { of the project }\left(D_{18}\right)\end{array}$ \\
\hline & & $\begin{array}{l}\text { Private sector satisfaction on risk allocation } \\
\left(\mathrm{D}_{19}\right)\end{array}$ \\
\hline & & $\begin{array}{l}\text { Private sector satisfaction on public private } \\
\text { partnership }\left(D_{20}\right)\end{array}$ \\
\hline & & $\begin{array}{l}\text { Private sector satisfaction on promised } \\
\text { subsidies by government }\left(\mathrm{D}_{21}\right)\end{array}$ \\
\hline & \multirow{3}{*}{ The public satisfaction $\left(\mathrm{C}_{8}\right)$} & $\begin{array}{l}\text { The public satisfaction on environmental } \\
\text { benefit of the project }\left(\mathrm{D}_{22}\right)\end{array}$ \\
\hline & & $\begin{array}{l}\text { The public satisfaction on social benefit of the } \\
\text { project }\left(D_{23}\right)\end{array}$ \\
\hline & & $\begin{array}{l}\text { Satisfaction of aging population on the service } \\
\text { quality of the project }\left(D_{24}\right)\end{array}$ \\
\hline \multirow{5}{*}{$\begin{array}{l}\text { Sustainable } \\
\text { development } \\
\text { performance } \\
\qquad\left(\mathrm{B}_{4}\right)\end{array}$} & \multirow{2}{*}{$\begin{array}{l}\text { Social development sustainable } \\
\text { performance }\left(\mathrm{C}_{9}\right)\end{array}$} & $\begin{array}{l}\text { Contribution to growing social pension } \\
\text { requirements }\left(D_{25}\right)\end{array}$ \\
\hline & & $\begin{array}{l}\text { Contribution to the improvement of social } \\
\text { pension quality }\left(D_{26}\right)\end{array}$ \\
\hline & \multirow{2}{*}{$\begin{array}{l}\text { Economic growth sustainable } \\
\text { performance }\left(\mathrm{C}_{10}\right)\end{array}$} & Regional investment GDP index $\left(\mathrm{D}_{27}\right)$ \\
\hline & & $\begin{array}{l}\text { Contribution to the development of regional } \\
\text { pension industry }\left(D_{28}\right)\end{array}$ \\
\hline & $\begin{array}{l}\text { Environment and resource } \\
\text { sustainable performance }\left(\mathrm{C}_{11}\right)\end{array}$ & $\begin{array}{l}\text { Influence on sustainable development of } \\
\text { natural environment }\left(\mathrm{D}_{29}\right)\end{array}$ \\
\hline
\end{tabular}

\section{Summary}

The aforesaid analyses provide ideas for the public sector in performance evaluation on pension institution PPP project and promote the improvement of its performance level indirectly. According to the national situation in China, in the future, the aging population demands more and more institution pension service and requires continuous improvement of service quality. Therefore, there is no doubt that the improvement of performance level of pension institution PPP project plays a 
significant role in promoting the satisfaction of those demands.

\section{References}

[1] HU Guixiang, WANG Qian. The Research of The necessity and application conditions of PPP mode applied to the construction of pension institution[J]. Construction Economy, 2012(2)

[2] WANG Jingling, HUA Long. The Study of The necessity of PPP mechanism applied to the construction of pension institution[J]. Review of Economic Research, 2014(52)

[3] Tingting Liu, Suzanne Wilkinson. Large - scale public venue development and the application of Public - Private Partnerships (PPPs)[J]. International Journal of Project Management, 2014

[4] Jui-Sheng Chou, H. Ping Tserng, Chieh Lin, Wen-Haw Huang. Strategic governance for modeling institutional framework of public - private partnerships[J]. Cities, 2015

[5] Eva I. Hoppe, David J. Kusterer, Patrick W. Schmitz . Public - private partnerships versus traditional procurement: An experimental investigation[J]. Journal of Economic Behavior \& Organization, 2013

[6] José Martins, Rui Cunha Marques, Carlos Oliveira Cruz. Maximizing the value for money of PPP arrangements through flexibility: An application to airports[J]. Journal of Air Transport Management, 2014

[7] Afeez Olalekan Sanni, Maizon Hashim. Building infrastructure through Public Private Partnerships in SubSaharan Africa: Lessons from South Africa[J]. Procedia - Social and Behavioral Sciences, 2014

[8] MU Guangzong. The Development Predicament and Countermeasure of pension institution in China [J]. Journal of Huazhong Normal University(Humanities and Social Sciences), 2012(2)

[9] CHEN Jia, FENG Changchun. The Development of Real Estate for the Senior Citizens in China[J]. Modern Urban Research, 2014(9)

[10] Ji Pengjiao. Research on Development Model of Old-age Real Estate in China[D]. Shanxi: Shanxi University of Finance \& Economics, 2014 